\title{
Bibliographic Instruction and Continuing Education
}

Virginia Ellis Palmer's suggestion ${ }^{1}$ that bibliographic instruction would fit nicely into a continuing education program has prompted me to share a very rewarding experience which $I$ had in combining bibliographic instruction and continuing education at the University of West Florida in Pensacola. Palmer's reference was to a course which she would like to see offered through the $\mathrm{CE}$ program, and my experience was with a workshop, but there are a few similarities in concept which I think are worth noting.

A study conducted at Indiana University has shown that the target audience for continuing education programs are those people who are seeking professional or occupational advancement. CE programs will appeal to both the intellectually curious and the university community at large. ${ }^{2}$

Workshops are also an excellent method that allows for more individual participation and hands-on experience with materials. They are designed for those with a specific learning need who participate as a matter of choice. Much of the bibliographic instruction which librarians currently provide is required of students who are reluctant to participate.

As a group, teachers have been the most avid seekers of professional or occupational advancement, whether by choice or by requirement. As academic librarians well know, each summer many educators return to the college campus to take courses for advanced degrees or certification. Many of them graduated before the use of the National Institute of Education's ERIC publications became widespread, and since much of their summer research necessitates use of the ERIC files, they may need to learn or re-learn search methodology.

This rationale was used when, in response to a request from the director of continuing education at the University of West Florida for workshop ideas, I wrote a formal proposal for a program in ERIC materials. The idea had been explored previously with a representative from the $\mathrm{Na}$ tional Institute of Education who had given me

${ }^{1}$ Virginia Ellis Palmer, "BI for the Invisible University," College and Research Libraries News 43 (January 1982):12-13.

${ }^{2}$ B.J. Chandler, ed., Standard Education Almanac 1981-1982 (Chicago: Marquis, 1981), p.276. not only a green light but also free booklets to distribute at the workshop.

My proposal was enthusiastically received by the director of continuing education as well as a representative from the local school system. Two workshops were scheduled (one on Wednesday morning and the other on Saturday) at a cost of $\$ 5$ for each participant.

The director of libraries, who had been asked to lend both hardware and software for use in the workshops, suggested that they be conducted as part of the library's Bibliographic Instruction Program. This was easily arranged with the Continuing Education Department, and the workshops came under joint sponsorship with all the items in my original proposal remaining intact.

The workshops were held in a public meeting room in the library last June at the beginning of Summer Quarter. The early date would allow participants to learn the ERIC search strategy in sufficient time to do class research and before they became too involved in their other courses. It also allowed others who were not returning to summer school a chance to rest from their teaching assignments and take part in the Saturday workshop before the summer was underway.

The Continuing Education Department provided publicity to both on-campus and off-campus newspapers. I also arranged for media coverage in a neighboring town and wrote letters to educators in nearby schools.

The objectives of the workshops were 1) to introduce ERIC and its network of clearinghouses; 2) to teach the use of the Thesaurus of ERIC Descriptors, the key to the ERIC indexing system; 3) to teach the use of Resources in Education and Current Index to Journals in Education for a manual search of the ERIC files; 4) to teach the operation of a microfiche machine for reading and reproducing ERIC materials on microfiche; and 5) to introduce participants to ERIC database searching.

The Saturday morning workshop proved to be the more popular of the two, despite the fact that most participants were connected to the university in some way. In addition to a librarian from a neighboring college, the participants were education faculty and local teachers working toward advanced degrees. Several teachers who attended expressed regret that they had not learned the benefits of awareness of ERIC publications when they had begun their graduate programs. 
Future workshops will examine more closely the ERIC database search strategy. In planning for upcoming workshops, I will stress to a greater degree that the workshops were designed for everyone involved in education, not just classroom teachers taking summer courses. The objectives of many clearinghouses across the country are to provide research materials to

\section{HERMAN KAHN TO SPEAK ON THE FUTURE}

A special feature of ACRL's program meeting in Philadelphia will be the address by Herman Kahn, chairman and director of research at the Hudson Institute, Croton-on-Hudson, New York. Kahn will speak on "How Social Change and Public Policy Will Affect Education and Information in the Decade Ahead" at the meeting, which will begin at 2:00 p.m. on July 12 at the University of Pennsylvania Faculty Club, a short distance from the conference site.

Kahn is a specialist in

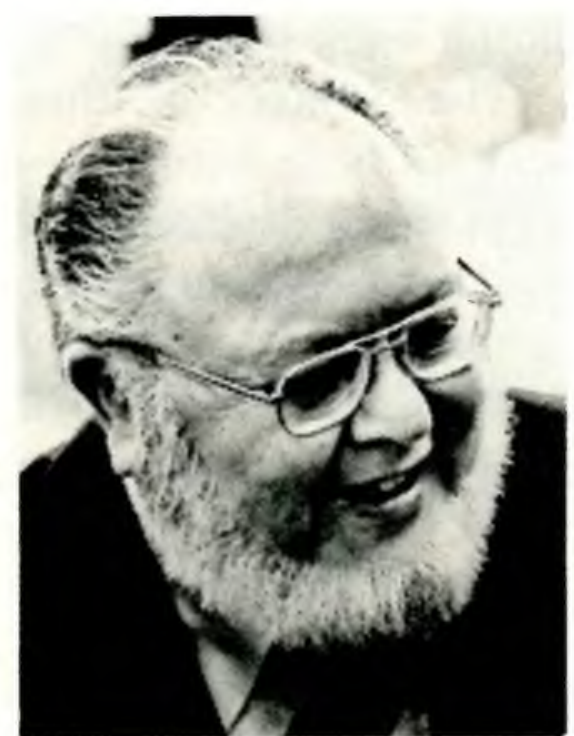

Herman Kahn public policy analysis and a co-founder of the Hudson Institute in 1961. The institute is a think tank that examines public policy issues related to long-range planning, U.S. national security, and international order. Kahn directed Hudson's work for the Commission on the Year 2000 of the American Academy of Arts and Sciences.

A futurist with an eye towards long-term cultural, economic, political, and technological trends, Kahn has authored and co-authored many books: On Thermonuclear War (1960); Thinking about the Unthinkable (1962); On Escalation (1965); The Year 2000 (with Anthony J. Wiener, 1967); Can We Win in Vietnam? (1968); Why ABM? (1969); The Emerging Japanese Superstate (1970); Things to Come (with B. Bruce-Briggs, 1972); The Next 200 Years (with William Brown and Leon Martel, 1976); World Economic Development (1979); The Japanese Challenge: The Success and Failure of Economic Success (with Thomas Pepper, 1979); and Will She Be Right? The Future of Australia (with Thomas Pepper, 1980).

From 1948 to $1960 \mathrm{Kahn}$ was a research associate at the RAND Corporation. In 1959 he was a visiting research associate at the Princeton Center for International Studies. He is currently a member of the Council on Foreign Relations (New York), the Center for Inter-American Relations, the American Political Science Association, Phi Beta Kappa, and Phi Mu Epsilon. teachers and administrators that will help them discover new information related to their interests and to assist them in applying this knowledge in their own situations.-Lois C. Gilmer.

Editor's Note: Lois C. Gilmer is interlibrary loans librarian at the University of West Florida, Pensacola.

Also speaking at ACRL's program meeting will be Frank Newman, president of the University of Rhode Island, who will address the topic, "The Decades Ahead for Colleges and Universities."

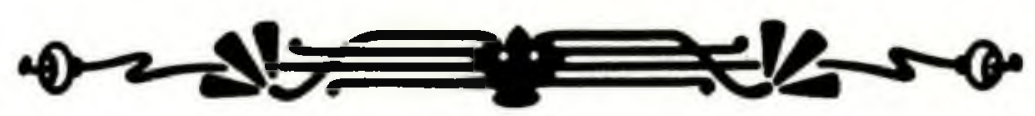

\section{BIS RECEIVES AWARD TO PUT ON WORKSHOPS}

The ACRL Bibliographic Instruction Section has been granted the J. Morris Jones World Book Encyclopedia ALA Goal Award by the ALA Goal Award Jury. The $\$ 5,000$ award is presented to ALA units to encourage and advance the development of librarianship through recognition and support of programs which implement the goal and objectives of ALA.

The winning project proposal, submitted by BIS chair Shelley E. Phipps, is entitled "Bringing Workshops to the Members" and consists of a series of workshops designed to increase the knowledge and skills of librarians involved in BI. The workshops, based on those previously conducted as preconference events, will be held on a regional level and conducted by nationally recognized leaders in bibliographic instruction.

ACRL chapters will be offered a menu from which they can choose one or two of the workshops that will best meet the needs of people in their state. Workshop leaders will then attend state library conferences to present their programs. The award will allow for eight of the workshops to be available to state associations on a partial cost-sharing basis.

The workshops to be offered are: "Teaching Librarians to Teach," "The One-Hour Stand," "Workbooks: Organization and Development," "Course-Related and Integrated Library Instruction," "Library Instruction for Faculty and Graduate Students," "Classroom Dynamics," "Conceptual Frameworks for Bibliographic Instruction," "Can Bibliographic Instruction Teach Students to Think?" and "Evaluation Tools and Tactics."

The procedures for applying for these workshops and the selection criteria have not yet been developed, but the ground rules will be drawn up and publicized in the near future.

For further information, contact Anne K. Beaubien, Michigan Information Transfer Source, University of Michigan, Ann Arbor, MI 48109. 


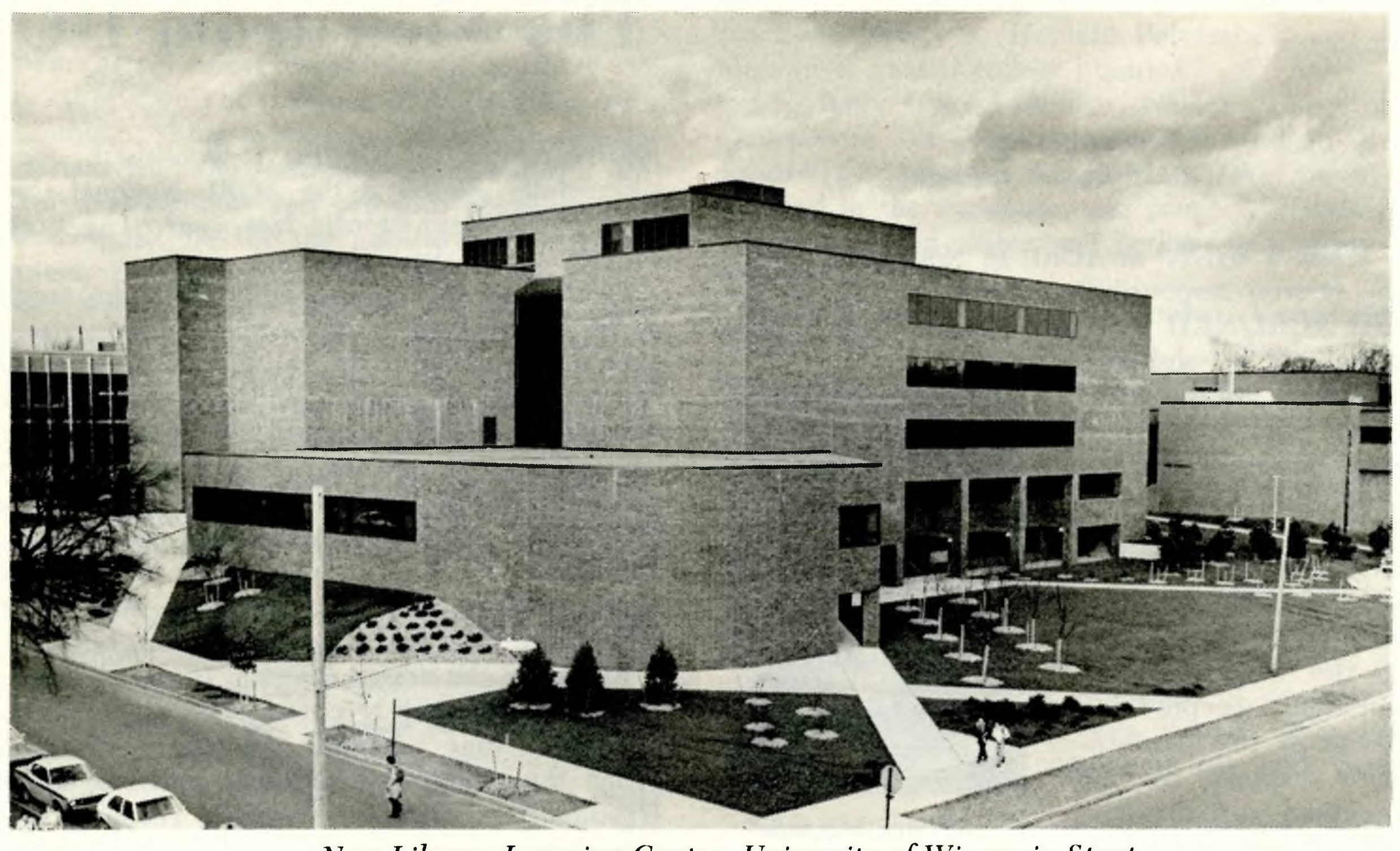

New Library Learning Center, University of Wisconsin-Stout.

UW-Stout

\section{NEW LRC DEDICATED}

Completion of the University of WisconsinStout's new \$6.7 million Library Learning Center represents more than a dozen years of planning and preparation. The new five-story facility was dedicated on April 24.

With more than 123,000 square feet of space, the building is nearly twice the size of the old Pierce Library located across the street. The old library opened in 1954 and an addition to it was completed in 1969. Joe Jax, library learning center director, said the need for a new library facility at Stout was recognized as early as 1970: "One of the biggest problems was that literally a third of the old building was constructed in the early 1950 s and was not air-conditioned. In the summer it was not unusual to have 90-95 degree te.nperatures in the periodical stacks, where there were only 7 -foot ceilings." Jax also said that arrangement of facilities within the building was poorly planned.

The new building provides users with many modern comforts. Non-print materials are integrated by subject with the printed materials. Apple microcomputers and terminals with access to the university's computer center are available on the fourth and fifth floors. An in-house telephone system allows users to ask for assistance from the circulation and reference desks. Service centers which provide tape recorders, copiers, computer terminals, and electric typewriters are centrally located on each floor.

Because the building was constructed for $\$ 1$ million less than was estimated, other frills could be added, including a natural cedarwood decor and a considerable amount of esthetically pleasing interior brick.

\section{ASSISTANCE TO THE DISABLED}

As more and more physically disabled students enter colleges and universities, it is increasingly important for academic libraries to maintain a staff that can meet the information needs of these special users. At ALA's Midwinter Meeting in Denver the executive board of the Library Service to the Blind and Physically Handicapped Section of the ALA Association of Specialized and Cooperative Library Agencies approved the formation of a new discussion group: Academic Librarians Assisting the Disabled (ALAD).

The organizational meeting of the discussion group will be held at ALA Annual Conference in Philadelphia at 9 a.m. on Sunday, July 11. The purposes of the group are to provide a forum for exchange of information about library services for the physically disabled in higher education; to provide the opportunity for the sharing of ideas, concerns, and solutions; and to increase the awareness of all academic librarians of the needs of the physically handicapped.

Visitors to the first meeting are invited to bring handouts, reports, examples, or outlines of programs that have been used successfully. For further information, contact: Betty-Ruth Wilson, Undergraduate Library, Southern Illinois University, Carbondale, IL 62901; (618) 453-2918. 